\title{
Two new mammalian teeth (Multituberculata and Peramura) from the Lower Cretaceous (Barremian) of Spain
}

\author{
$\star$ José Ignacio Canudo and †Gloria Cuenca-Bescós \\ * Museo Paleontológico de la Universidad de Zaragoza, 50009 Zaragoza, Spain \\ † Departamento de Ciencias de la Tierra, Universidad de Zaragoza, 50009 Zaragoza, Spain \\ Revised manuscript accepted 14 November 1995
}

\begin{abstract}
Early Cretaceous mammals of Spain are known only from the Galve and Uña areas. They are of considerable importance when compared with other Early Cretaceous mammal assemblages, and are the only known assemblage from the Barremian. In this context, two new mammalian taxa from Poca, Galve (Teruel) are described: Lavocatia alfambrensis gen. nov., sp. nov. (Multituberculata) based upon P5, and Pocamus pepelui gen. nov., sp. nov. (Peramura) also based upon P5. Lavocatia, because of its similarity to Kielanodon, is assigned to the Paulchoffatiinae. It differs from known paulchoffatiine genera in having a large number of cusps (15), rather than eight or 10, which are arranged in three oblique, rather than longitudinal, rows. Pocamus is assigned to the Peramura. It generally resembles Peramus, from which it differs in having a third cusp interpreted as an incipient protocone.
\end{abstract}

(C) 1996 Academic Press Limited

KEY WorDS: Early Cretaceous; Spain; systematics; Multituberculata; Paulchoffatiidae; Eupantotheria; Peramura.

\section{Introduction}

The history of the Mammalia during the Jurassic and Early Cretaceous is one of the most interesting, yet poorly documented, phases of mammalian evolution. In the book of Lillegraven et al. (1979), there are references to virtually all papers of significance concerning the systematics and evolution of Mesozoic mammals. New finds and studies have increased knowledge of this group in the last 15 years; for example, Early Cretaceous faunas from South America and Africa (Bonaparte \& Rougier, 1987; Brunet et al., 1988; Jacobs et al., 1988; SigogneauRussell, 1988) were unknown before the mid-eighties.

Mammals are known from about a dozen Lower Cretaceous localities, and for the Barremian, the Spanish sites Galve and Uña are the only ones known worldwide (Crusafont \& Adrover, 1966; Kühne, 1966; Kühne \& Crusafont, 1968; Henkel \& Krebs, 1969; Crusafont \& Gibert, 1976; Clemens et al., 1979; Krebs, 1980, 1985; Hahn \& Hahn, 1992; Hahn, 1993). Galve is a village in the Aliaga Basin, some $40 \mathrm{~km}$ north of Teruel, northeast Spain (Figure 1). The Galve region is justifiably famous for its archosaur fauna (Sanz, 1987; Buscalioni \& Sanz, 1990) and for the mammal assemblages (Figure 2) from Cerrada Roya mina (CRm), Herrero ( $\mathrm{YH})$, Colladico Blanco (CB or Galve Th in German literature; i.e. Krebs, 1985, 1993), and 'P' (Hahn \& Hahn, 1992; Krebs, 1993; Cuenca-Bescós et al., 1994).

During the Early Cretaceous, a widespread break-up of the Late Jurassic Iberian carbonate platform took place, resulting in the genesis of several rapidly subsiding sub-basins. These sub-basins, such as Aliaga (Rama Castellana of the 


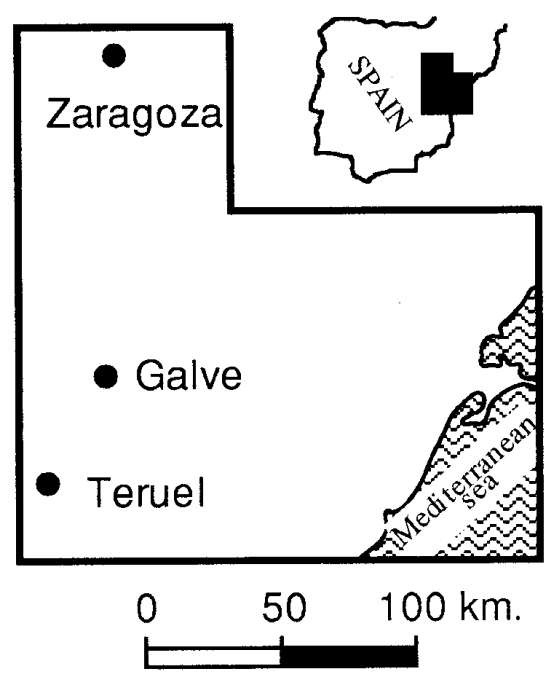

Figure 1. Location map of Galve, Teruel, Spain.

Iberian Range), were filled with Early Cretaceous continental sedimentary units known in the local literature as Wealden facies. The outcrops at Galve comprise part of the Galve syncline, a nearly 1-km-thick succession of shallow marine and continental Jurassic and Lower Cretaceous sedimentary units (Figure 2), ranging in age from late Tithonian to late Barremian-Aptian (Díaz-Molina et al., 1984; Soria et al., 1995). The Galve succession can be divided into five units, characterized by facies associations. From bottom to top these are the Higueruelas, Villar del Arzobispo, Castellar, Camarillas and Artoles Formations. The Higueruelas and Villar del Arzobispo Formations (Tithonian-Berriasian) represent the highest sequence of the ancient Jurassic shelf. In the upper levels of the Villar del Arzobispo Fm., biogenic sedimentary structures dominated by dinosaur tracks, record the first shallow marine environments that mark the transition between marine and continental units in the Galve section (Soria et al., 1995).

The first recorded continental sedimentary units are late Hauterivian-early Barremian (Castellar and Camarillas Formations). The CB and ' $\mathrm{P}$ ' sites are located at the top of the Castellar Fm. (Unit 4 of Diaz-Molina et al., 1984) in coastal lacustrine facies dominated by grey marls and bioturbated limestone known as the Colladico Blanco level. The YH site is located at the bottom of the Camarillas Fm. (Unit 5 of Diaz-Molina et al., 1984), in the flood plain-channel facies of this formation. The CRm site is located in the middle part of the Camarillas Fm. The two new mammalian teeth were found at Poca, a locality situated in the uppermost part of the Camarillas Fm. dominated by fluviolacustrine clays with quartz grains. Revision of charophytes and pollen-spore assemblages confirms the lower Barremian stratigraphic position of the uppermost part of Castellar and Camarillas Formations (Mohr, 1987; Schudack; 1989; Martín-Closas, 1989). In the upper part of the Galve section, evidence for marine sedimentation in the Aliaga Sub-basin is found in upper Barremian again, and higher strata, in the Artoles Formation (Soria et al., 1995). A complete stratigraphic study is provided by Diaz-Molina et al. (1984) and Soria et al. (1995).

The Poca locality contains a vertebrate assemblage of bones and teeth of fish, 


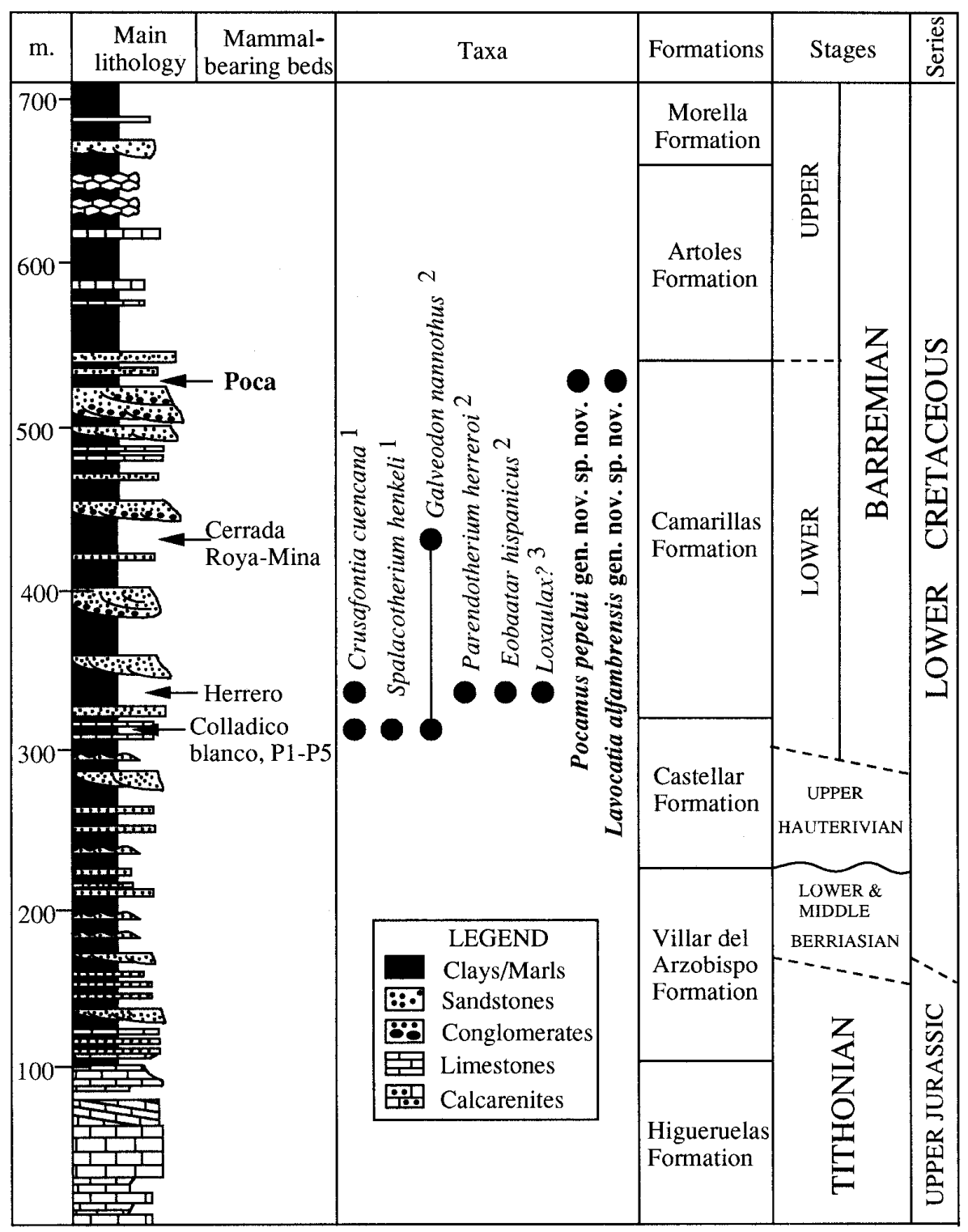

Figure 2. Lithology and details of the section at Galve, Teruel. The figure shows a composite section of the sedimentary units located in the Galve syncline, including both the thickness and main lithologies of the Upper Jurassic to Lower Cretaceous units and the known mammalian distribution. The graphic log and stratigraphic position of mammal localities are after CuencaBescós et al. (1994, redrawn and modified). Mammals from the localities Herrero (YH), Colladico Blanco (CB, CRM), 'P'-1, 'P'-5 and Cerrada Roya-Mina have been studied by Krebs ${ }^{1}$ (1985, 1993) and Hahn \& $\mathrm{Hahn}^{2}$ (1992). The mammals from Poca are described here ${ }^{3}$.

amphibians, reptiles (Richter, 1994), and very scarce mammals (Figure 2). To find the minute mammalian fossils, a large quantity of rock (500 kg) was processed by José María Herrero (a local amateur). The material was washed with water and then passed through a set of graded sieves $(>0.5 \mathrm{~mm})$. The aim of this paper is to describe the two mammalian teeth obtained in this first recovery of Poca vertebrates. 


\section{Systematic palaeontology}

Tooth abbreviations and dental measurements

Generalized mammalian dentition has four classes: incisors, canines, premolars and molars. The letters are abbreviations for the classes (I, C, P, M). For each half of each jaw, the basic or generalized dentition for multituberculates is two to three incisor teeth, one canine, four to five premolariform teeth and two molars (Kielan-Jaworowska \& Ensom, 1992; Hahn, 1971, 1993). The basic dentition for peramuran-eupantotherian mammals is four incisor teeth, one canine, five premolars and three molars (McKenna, 1975; Bown \& Kraus, 1979; Kraus, 1979; Prothero, 1981). The teeth in each class are numbered away from the median sagittal plane. Hence, the most mesial or anterior incisor is the first incisor and the most distal, the third. The numbers are assigned on the basis of the generalized mammalian dentition. We use in this work upper case letters for the upper teeth (P5, M1) and lower case for the lower teeth (p5, m1). The teeth were measured using a calibrated micrometer eyepiece in an Olympus SZH binocular microscope. The tooth measurements are L (anteroposterior length) and $\mathrm{W}$ (width of tooth), maximum mesiodistal and buccolingual dimensions respectively.

Table 1 lists the taxa cited in the text. Its purpose is to summarize the information available for each taxon and to clarify the text by avoiding repetitive data.

The two specimens described are housed in the Museo Paleontológico de la Universidad de Zaragoza, and labelled MPZ 95/172 and MPZ 95/173.

Order Multituberculata Cope 1884

Suborder Plagiaulacoidea (Simpson, 1925) Hahn 1969

Family Paulchoffatiidae Hahn 1969

Kielan-Jaworowska \& Ensom (1992) and Hahn (1993) revised the high-level taxonomy of the Late Jurassic and Early Cretaceous multituberculates. We follow the systematic arrangement of the Paulchoffatiidae proposed by Hahn (1993), and therefore include the Family Paulchoffatiidae in the Plagiaulacoidea. We employ the general classification of Mesozoic Multituberculata of Clemens \& Kielan-Jaworowska (1979) in general discussion.

Subfamily Paulchoffatiinae Hahn 1971

Lavocatia alfambrensis gen. nov., sp. nov. Figure 3.1-6

Material and measurements. Specimen MPZ 95/172 (holotype): a right P5; $\mathrm{L}=1.43 \times \mathrm{W}=0.90$. It is a crown without roots.

Derivatio nominis. Lavocatia, in honour of Professor René Lavocat (Montpellier) in recognition of his work on fossil vertebrates, especially mammals; alfambrensis, after the river Alfambra that runs through Galve.

Type horizon and locality. Upper part of the Camarillas Formation, Aliaga Basin, Poca locality, near Galve (Teruel, Iberian Range, Spain); lower Barremian.

Diagnosis. A paulchoffatiid with elongated, longer than broad, P5. Cusp formula 4:6:5. Middle row longer than lingual and buccal rows; lingual row shorter than buccal. Rows are oblique to the anteroposterior axis. 


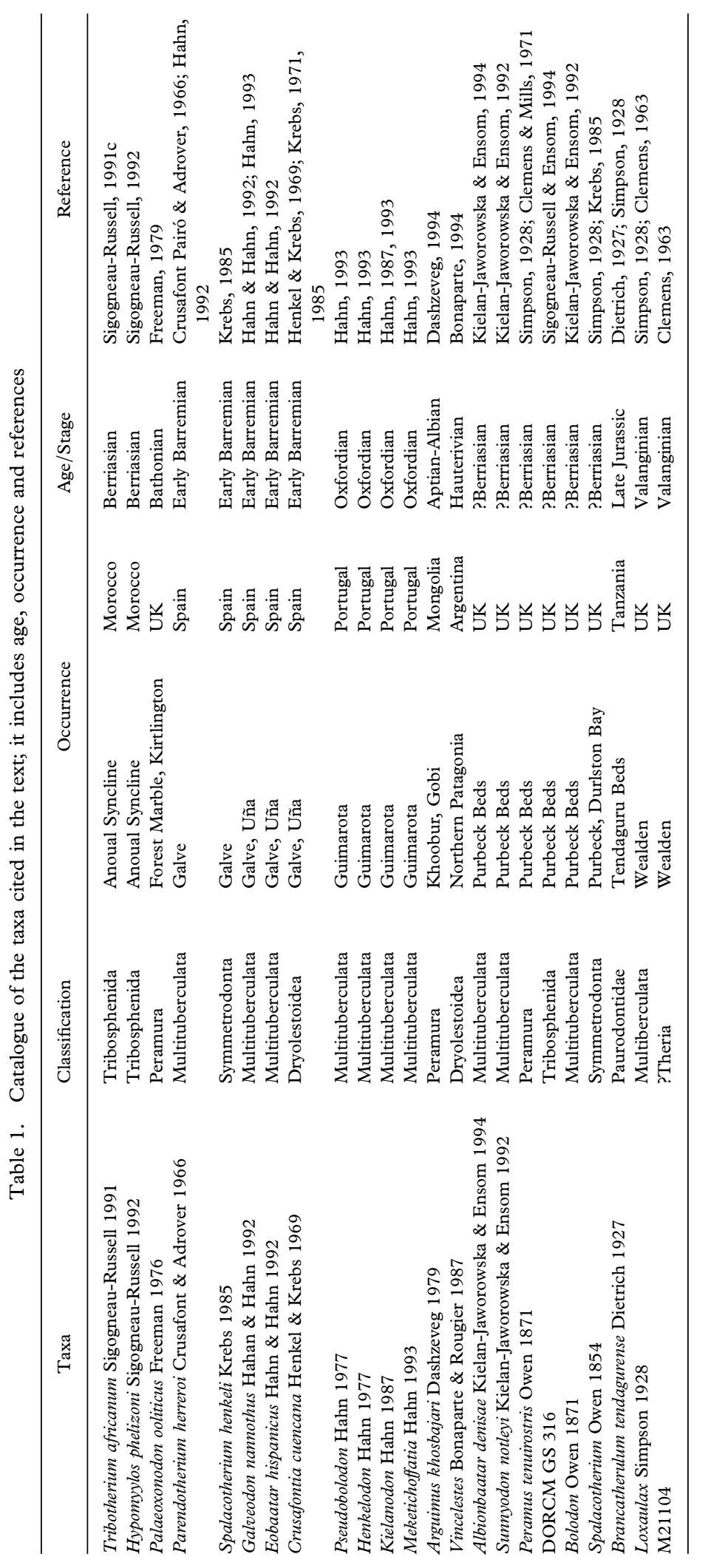




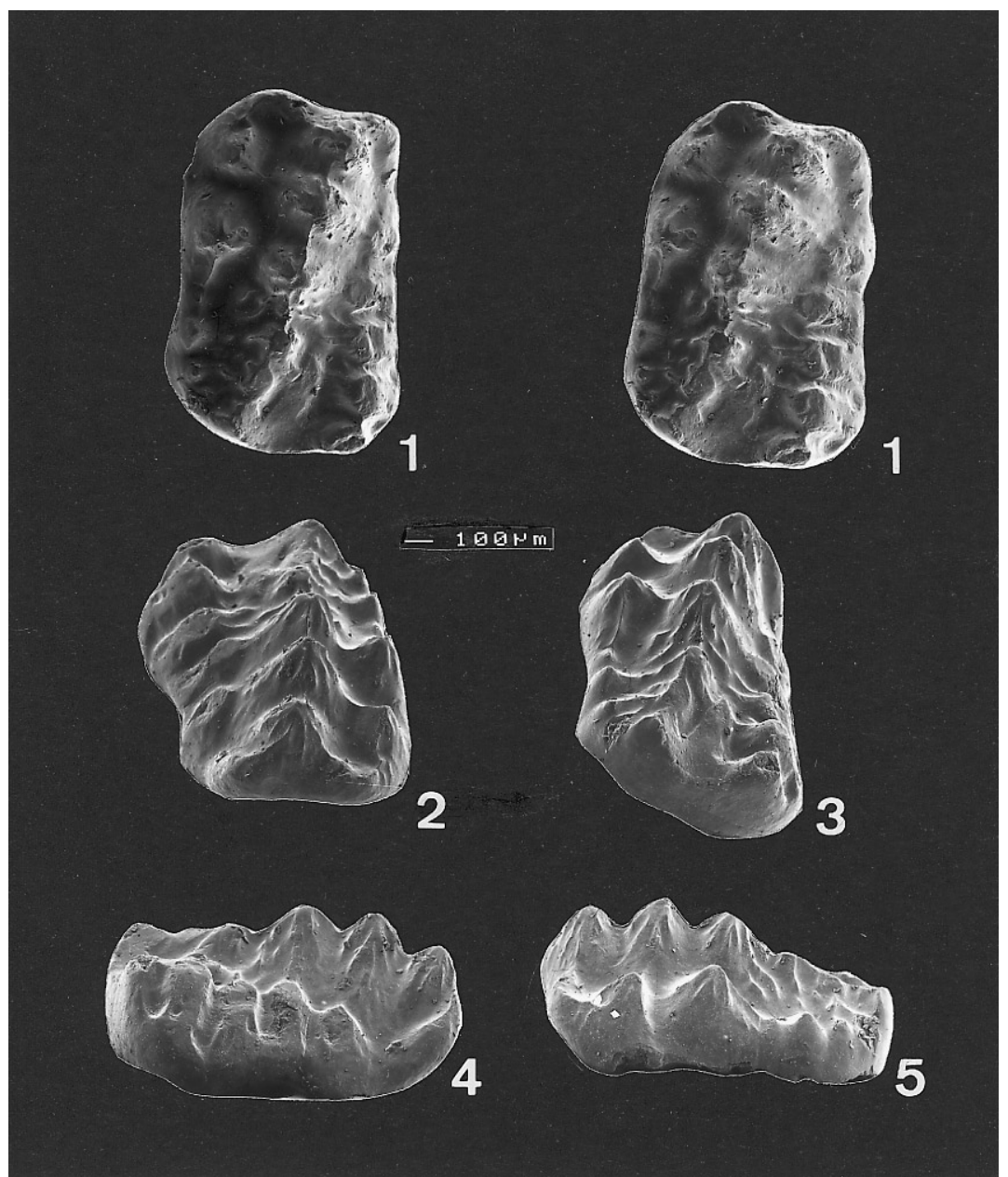

Figure 3. Lavocatia alfambrensis gen. nov. sp. nov. (holotype, MPZ 95/172). Right P5: 1 (stereo-pair) occlusal; 2, anterior; 3, posterior; 4, lingual and 5, labial views.

Description. The only tooth available is a right P5. The crown is roughly rectangular in occlusal view, slightly wider posteriorly than anteriorly (Figure 3.1, 2). Buccal margin is almost straight. Lingual margin is somewhat irregular, concave in the middle. Anterior margin is concave in the middle. Posterior margin is gently rounded, slightly convex in the middle.

There are three rows of conical cusps. The cusps in lingual and buccal rows are smaller than those in the middle row. The largest cusps are situated anteriorly, three of the middle row and two of the buccal row, and they are covered by diverging or radiating ridges.

On the lingual side, the cusps are abraded by wear facets (shearing surfaces sensu Crompton \& Kielan-Jaworowska, 1978). The wear facets are triangular in shape, nearly vertical in the three anterior, and gently sloping in the two posterior, cusps (Figure 3.5). There is another, almost flat, wear facet; it is gently inclined from anterior to posterior, and occupies the posterior part of the valley between the middle and lingual rows of cusps (Figure 3.4). 
Distinction, comparison and discussion. The new genus Lavocatia has the characteristic upper premolars of multituberculates: these bear conical cusps covered by radiating ridges (Kielan-Jaworowska \& Ensom, 1994). Lavocatia shares with the paulchoffatiine Pseudobolodon Hahn 1977, Henkelodon Hahn 1977, Kielanodon Hahn 1987 and Meketichoffatia Hahn 1993, three rows of cusps in P5. Following Hahn $(1971,1993)$, the Paulchoffatiidae are divided into two subfamilies, the Paulchoffatiinae with three rows of cusps in P5, and the Kuehneodontinae Hahn 1971 with two rows; therefore we include Lavocatia in the Paulchoffatiinae.

As in Lavocatia, the rows are slightly oblique in Kielanodon and are oriented buccoposteriorly to anterolingually, but the genus Kielanodon has a cusp formula 2(or 4):4:2 (in the buccal row of Kielanodon there are two very small prominences that cannot be included in the number of cusps; Hahn, 1987, fig. 8). The lingual wall of P5 is vertically eroded in Kielanodon (see Hahn, 1987, 1993) and in Lavocatia. Lavocatia differs from Kielanodon and the rest of the paulchoffatiines in having a higher number of cusps in each row (the total number of cusps is 15 instead of 10 or less) and in being smaller.

The small size and the three rows of cusps of Lavocatia are comparable to the plagiaulacoid Albionbaatar denisae Kielan-Jaworowska \& Ensom 1994, but the genus differs from this species in having a smaller number of cusps in P5 and an approximately rectangular shape, instead of the 8-shape of Albionbaatar. The P5 of Lavocatia has cusps of different sizes and it is less flat than the premolars of Albionbaataridae described by Kielan-Jaworowska \& Ensom (1994). These authors discussed the allocation of Albionbaataridae within the multituberculates and arrived at the conclusion that the number of cusps, their similar size, the extensive lingual slope covered by transverse ridges, and the much more elongated fifth upper premolar (P5), make the Albionbaataridae different from the Paulchoffatoidea. This, together with the fact that the rows of Lavocatia form an angle with the buccal margin, leads us to reject the assignment of Lavocatia to the Albionbaataridae.

The plagiaulacoids Bolodon Owen 1871 and Sunnyodon Kielan-Jaworowska \& Ensom 1992 have three rows of cusps, or at least one or several small cusps in the buccal margin, forming an irregular row. These rows are approximately parallel to the buccal-lingual margins.

The Eobaatarinae (sensu Kielan-Jaworowska et al., 1987 and KielanJaworowska \& Ensom, 1992) have P5 with two rows of cusps; the cusp formula of Eobaatar Kielan-Jaworowska, Dashzeveg \& Trofimov 1987 is 2:4. The eobaatarines Eobaatar and Monobaatar Kielan-Jaworowska, Dashzeveg \& Trofimov 1987 have cusps ornamented with ridges, and in front of the anterior cusp of the labial row there is, in some specimens, a small cuspule that cannot be considered as a third row of cusps. The eobaatarine (sensu Kielan-Jaworowska \& Ensom, 1992) Loxaulax Simpson 1928, has cusps slightly ornamented with ridges (Clemens \& Lees, 1971), but they are not comparable to the dense, prominent and diverging ridges of Lavocatia. The three rows of cusps and the closely spaced ridges allow us to exclude Lavocatia from the Eobataarinae.

The genus Galveodon Hahn \& Hahn 1992 is represented by I2 and p3 or 4 (Hahn, 1993) and its small size is comparable to that in Lavocatia, which is also relatively small. It is, however, currently impossible to combine Lavocatia and Galveodon into a single taxon. As long as we have at hand only these fragmentary specimens, and because their stratigraphic records differ (Figure 2), it is better to maintain them as separate taxa. Other multituberculates from Galve such as 
Loxaulax sp. (Cuenca et al., 1995) are significantly larger than Lavocatia and cannot be related to it.

Parendotherium herreroi Crusafont-Pairó \& Adrover 1966 from YH was the first Mesozoic mammal to be described from Spain (Crusafont-Pairó \& Adrover, 1966). It was identified as a Plagiaulacidae by Hahn \& Hahn (1992), and is characterized by having two rows of cusps in P5. Thus, it differs from Lavocatia in having two rows of cusps instead of three.

Finally, the genus Lavocatia differs from the Late Cretaceous and early Tertiary multituberculates Ptilodontoidea and Taeniolabidoidea in having oblique rather than parallel rows of cusps, although in derived forms there is a third row of cusps on the molars (Clemens \& Kielan-Jaworowska, 1979).

\section{Infraclass Peramura McKenna 1975}

We use the taxon Peramura proposed by McKenna (1975) for peramurids but the term Eupantotheria in the sense of Kielan-Jaworowska (1992). Although McKenna (1975) and Prothero (1981) suggested that because eupantotheres are a paraphyletic group the term should not be used, we continue to refer to eupantotheres as this has become widely accepted unlike the new terms proposed by these authors. We include in Peramura the taxa Peramuridae Kretzoi 1960 and Arguimuridae Dashzeveg 1994 (which includes the Porto Pinheiro molar; Dashzeveg, 1994) and, questionably, Palaeoxonodon Freeman 1976 and Brancatherulum Dietrich 1927 (Kraus, 1979). Peramus, the type genus of Peramura, had been classified for many years as a paurodontid (Simpson, 1928) but the studies of Clemens (1971) and Clemens \& Mills (1971) on Peramus, and Kraus (1979) and Bakker et al. (1990) on paurodontids have provided adequate justification for placing Peramus and related forms in a separate infraclass. Clemens \& Mills (1971) demonstrated that Peramus and related forms, such as the new genus Pocamus here, have several characters that set them apart from all other eupantotheres; namely reduction in the number of molars (three instead of four or five as in Amphitheriidae, Paurodontidae and Dryolestidae; Kraus, 1979) and the tricuspid, incipiently basined condition of the molars.

Family Peramuridae Kretzoi, 1960

McKenna (1975) thought Peramus Owen 1871 had five premolars and three molars; therefore, the teeth called M1 or $\mathrm{m} 1$ by Clemens \& Mills (1971) are labelled P5 or p5 by McKenna (1975) and Prothero (1981); we accept the view of the latter authors and use P5 for the premolariform tooth found at Poca.

Pocamus pepelui gen. nov., sp. nov.

Figure 4.1-6

Material and measurements. Specimen MPZ 95/173 (holotype): right P5. L= $0.72 \times \mathrm{W}=0.37$. It is a crown, slightly broken on its lingual side, without roots.

Derivatio nominis. After Poca, the locality in which the tooth was found; pepelui, in honour of Professor Jose Luis Sanz, for his work on the Mesozoic vertebrates of Spain.

Type horizon and locality. Upper part of the Camarillas Formation, Aliaga Basin, Poca locality, near Galve (Teruel, Iberian Range, Spain); lower Barremian.

Diagnosis. A high paracone dominates the crown, and is located antero-lingually. The second main cusp, identified as a metacone, is lower, smaller, and located in 
the distal end of the tooth. On the lingual side of both cusps, a ridge runs from the tip of the paracone to the tip of the metacone, and in between is a distinct, oval-shaped shearing surface that resembles a shearing surface of a third cusp (an incipient protocone?). On the antero-labial slope of the paracone there is a small, eight-shaped cusp, the parastyle.

Description. The tooth is longer than wide, triangular in labial view (Figure 4.1) and roughly oval in occlusal view (Figure 4.3, 4.5, 4.6). The key to the orientation is given by the high main cusp, identified as a paracone, and the small labial cusp or parastyle, both situated on the anterior part of the tooth. There is a forerunner of the protocone on the lingual side of the paracone. The metacone is more conspicuous in labial view (Figure 4.1). From the metacone there is a low ridge which runs from its tip to the buco-distal margin of the tooth and, at its bottom, a small cuspule is present which lies adjacent to the larger cusp. This cuspule is conspicuous only in the lingual and posterior views (Figure 4.2, 4.3); in labial view it rather resembles a posterior cingulum (Figure 4.1).

Distinction, comparison and discussion. P5 of Pocamus pepelui resembles P5 of Peramus tenuirostris Owen 1871 from the Purbeck Beds at Durlston Bay, southern England (Clemens \& Mills, 1971). The new genus Pocamus differs from Peramus in lacking a cingulum on the lingual surface and a mesiolingual shelf carrying two cusps. The P5 of Pocamus has a metacone that is more distally placed than in $P$. tenuirostris. Pocamus differs from P5 in Peramus in having a higher and broader metacone, and an incipient protocone. We identify the small, labial cusp as a parastyle because this cusp is very similar to $P$. tenuirostris in P5.

Between the paracone and metacone there is a large shearing surface (Figure 4) that may be interpreted as an incipient protocone. Determination of the homologies of this feature is open to question; the protocone is a shared derived character uniting the Tribosphenida sensu Prothero (1981) and its interpretation is important in determining the relationships between Pocamus (Peramura) and the Tribosphenida. The cladogram proposed by Prothero (1981) shows Peramura as a sister group of the Tribosphenida, being the last group characterized by the addition of a protocone. As we propound the large shearing surface of Pocamus to be an incipient protocone and include this genus in Peramura, we postulate that Peramura shares with Tribosphenida the derived condition of a protocone and reduced dental formula.

The Anoual Syncline littoral sediments from the Berriasian of Morocco have yielded an advanced form of Theria: Tribotherium africanum Sigogneau-Russell 1991. The derived characters of Tribotherium, with a well developed protocone in upper molars, exclude the allocation of Pocamus with the forms related with Tribotherium. Other Moroccan therians such as Hypomylos Sigogneau-Russell 1992 are represented by lower molars, making comparison with Pocamus difficult. Nevertheless, Sigogneau-Russell (1992) compares the genus with Peramus, concluding that the degree of the development of the molar traits of Peramus is less derived than that of Hypomylos.

A fragment of a tooth found at Sunnydown Farm Quarry, Dorset, in the Purbeck Limestone Group, Lulworth Fm. (Sigogneau-Russell \& Ensom, 1994; specimen DORCM GS 316) is interpreted as the talonid of a tribosphenic molar. This fragment of a lower tooth cannot be compared with Pocamus; nevertheless, the closest genus, Peramus, is interpreted by the authors as very similar to the Sunnydown fragment. Peramus was also found in the Purbeck Limestone Group, 


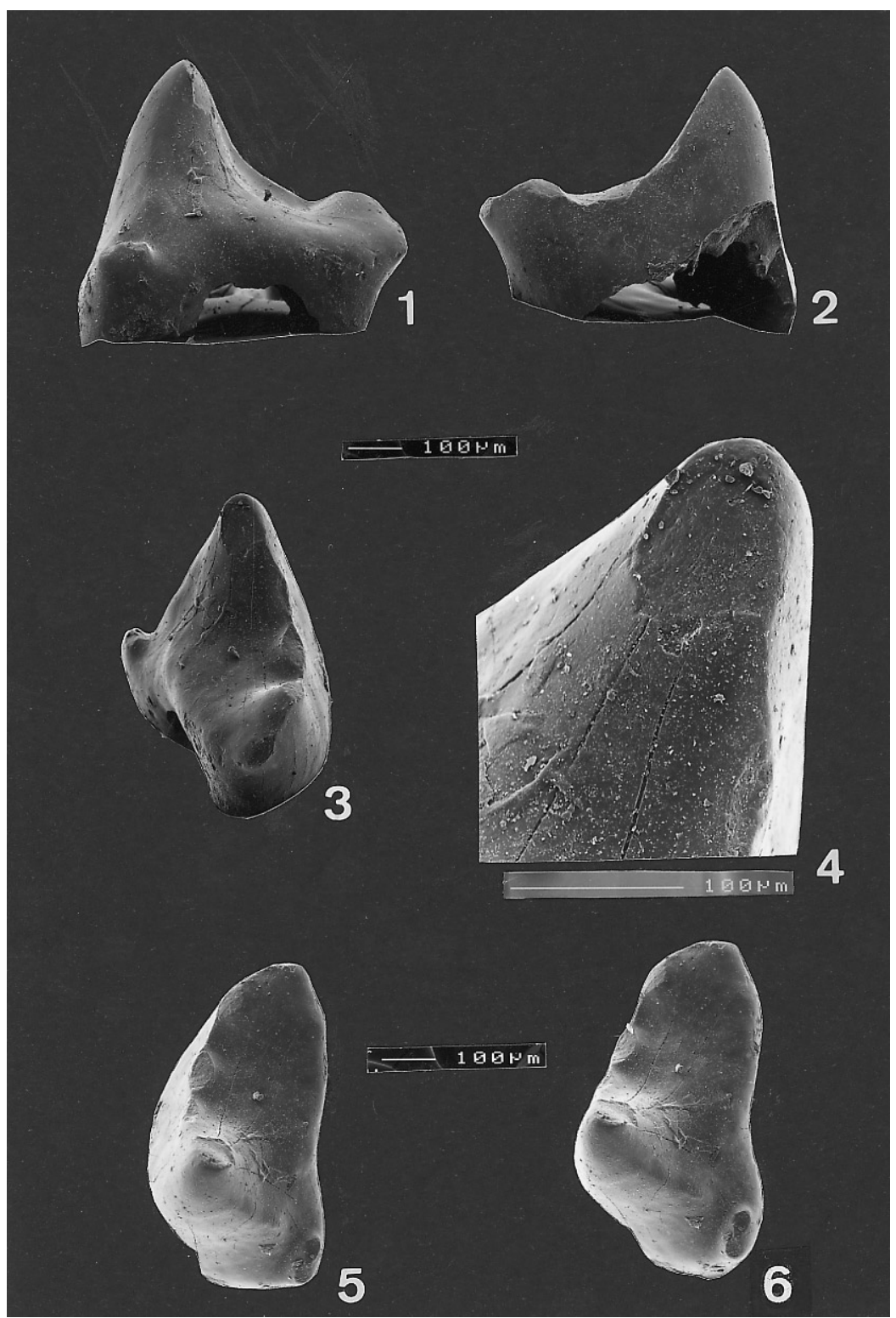

Figure 4. Pocamus pepelui gen. nov., sp. nov. (holotype, MPZ 95/173). Right M1 or P5. 1, labial; 2, lingual and 3, posterior views. 4, Detail of wear surface of paracone in posterior view. 5, 6, occlusal view, stereo-pair.

at the Dorset locality Durlston (or Durdlestone) Bay, in the upper part of the Lulworth Beds, stratigraphically similar to the locality from which the Sunnydown tooth was described by Sigogneau-Russell \& Ensom (1994, fig. 1). These authors interpreted the Sunnydown tooth to be the oldest evidence of tribosphenic mammals and Peramus to be a living fossil for its time; and also to indicate that tribosphenic innovation occurred in the Late Jurassic at the latest. If this interpretation is correct, the genus Pocamus could be one of the latest representatives of the Peramura, a group retaining the primitive character of an absent or 
incipient protocone (the Purbeck Limestone Group has been considered to be Late Jurassic, but palaeontological evidence suggests that much of the Lulworth Formation is Berriasian; Clemens et al., 1979; Sigogneau-Russell \& Ensom, 1994).

The oldest known peramurid is Palaeoxonodon ooliticus Freeman 1976, found in the upper Bathonian Forest Marble of the Old Cement Works Quarry, Kirtlington, Oxfordshire (Freeman, 1979). Again, the lower molars are comparable with Peramus, being very close to this genus according to Freeman (1979). An upper molar of P. ooliticus is preserved and, like Peramus, there is no protocone on the lingual side of the paracone. If our interpretation is correct, then the new genus Pocamus should be highly evolved in relation to the development of the protocone in Palaeoxonodon and Peramus.

The diagnosis of Arguimus khosbajari Dashzeveg 1979, from the Lower Cretaceous (Aptian-Albian) Khovbur Beds in the Gobi Desert (Dashzeveg, 1979, 1994), is based on lower dentition; hence it is difficult to compare with the upper tooth of Pocamus. We can make only a few remarks on the general tooth characters of both genera. In $A$. khosbajari, the last premolars are more molariform than those of $P$. tenuirostris; thus, being Arguimuridae, they are more advanced than the Peramuridae. The Porto Pinheiro molar, which is included in Arguimuridae by Dahzeveg (1994) is also a lower molariform tooth with a trigonid resembling that of Peramus, and a well-developed talonid basin being, together with Palaeoxonodon, one of the earliest occurrences of a distinctly basined talonid.

Other therians from Galve are different. One is the symmetrodont Spalacotherium Owen 1854, and another is the driolestid Crusafontia cuencana Henkel \& Krebs 1969. The molars of symmetrodonts are characterized by a continuous basal cingulum around the crown and can bear cuspules. In some advanced forms, such as Spalacotherium henkeli Krebs 1985 from Galve (Galve Th 13, 15), the cingulum is not continuous or very reduced; generally the external or labial cingulum is well-developed and the internal or lingual cingulum is missing, as in Galve Th 15 (Krebs, 1985). The dryolestid Crusafontia shows, in some aspects, a morphology that is parallel to the ancestors of the modern Theria (Henkel \& Krebs, 1969); the cingulum is missing in premolars as in Pocamus, but typical dryolestids have upper molars that are much broader than long (Kraus, 1979; Krebs, 1985).

Clemens (1963) described from the Paddockhurst Bone Bed of the Wealden of England, a small premolariform tooth that consists of a large, central cusp and smaller anterior and posterior accessory cusps (specimen M21104, classified by Clemens, 1963 as ?Theria) aligned mesiodistally. This alignment is certainly different from the more or less oval arrangement of the cusps of Pocamus.

Finally, the only pre-tribosphenic mammal with a well described forerunner protocone in the upper molars is Vincelestes Bonaparte \& Rougier 1987 from the Hauterivian of northern Patagonia, Argentina (Bonaparte, 1994). The upper premolar of this genus is very simple in comparison with that of Pocamus, and no trace of protocone is seen.

\section{Conclusion}

The teeth from Galve and Uña are the only mammalian remains of Barremian age known. Our work has shown that Galve is not a single vertebrate locality but 
a thick succession of nearly $1 \mathrm{~km}$ of marine and continental units, ranging from late Tithonian to late Barremian-Aptian in age. It has several vertebrate-bearing levels, at least three of which (all Barremian) contain mammals. The two new mammalian species described were recovered from levels at the top of the Camarillas Formation.

\section{Acknowledgements}

Prof. Kielan-Jaworowska kindly read an early draft of this paper and offered most useful comments and criticism. Thanks are due also to Dr. Sigogneau-Russell and one anonymous reviewer for their suggestions which greatly improved the manuscript. Mr José María Herrero collected the material for this study. Mme Cristina Gallego, Servicio de Microscopía Electrónica, Zaragoza University, took the scanning electron micrographs. The Consejo Asesor de Investigación (CONAI, PCB 0693) provided financial support.

\section{References}

Bakker, R. T., Carpenter, K., Galton, P., Siegwarth, J. \& Filla, J. 1990. A new latest Jurassic vertebrate fauna from the highest levels of the Morrison Formation at Como Bluff, Wyoming, with comments on Morrison biochronology. Hunteria 2, 1-19.

Bonaparte, J. 1994. Approach to the significance of the Late Cretaceous mammals of South America. Berliner Geowissenkunde Abhandlungen 13, 31-44.

Bonaparte, J. \& Rougier, G. W. 1987. Mamíferos del Cretácico Inferior de Patagonia. Memorias IV Congreso Latinoamericano de Paleontología 1, 343-359.

Bown, T. M. \& Kraus M. J. 1979. Origin of the tribosphenic molar and metatherian and eutherian dental formulae. In Mesozoic mammals: the first two-thirds of mammalian history (eds Lillegraven, J. A., Kielan-Jaworowska, Z. \& Clemens, W. A.), pp. 172-181 (University of California Press, Berkeley).

Brunet, M., Jacobs, L., Congleton, J., Coppens, Y., Dejax, J., Flynn, L., Hell, J., Jehenne, Y., Mouchelin, G. \& Pilbeam, D. 1988. Première découverte d'un fragment de mandibule de Mammifére dans le Crétacé inférieur d'Afrique (Cameroun, Bassin de Koum). Comptes Rendues de la Académie des Sciences, Paris, II 307, 1675-1680.

Buscalioni, A. D. \& Sanz, J. L. 1990. The small crocodile Bernissartia fagesii from the Lower Cretaceous of Galve (Teruel, Spain). Bulletin de l'Institut Royal des Sciences Naturelles de Belgique, Sciences de la Terre 60, 129-150.

Clemens, W. A. 1963. Wealden mammalian fossils. Palaeontology 6, 55-69.

Clemens, W. A. 1971. Mammalian evolution in the Cretaceous. In Early mammals (eds Kermack, D.M. \& Kermack K.A.), Supplement 1, Zoological fournal of the Linnean Society 50, 165-180.

Clemens, W. A. \& Kielan-Jaworowska, Z. 1979. Multituberculata. In Mesozoic mammals: the first two-thirds of mammalian history (eds Lillegraven, J. A., Kielan-Jaworowska, Z. \& Clemens, W. A.), pp. 99-149. (University of California Press, Berkeley).

Clemens, W. A. \& Lees, P. M. 1971. A review of English Early Cretaceous mammals. In Early mammals (eds Kermack, D.M. \& Kermack K.A.), Supplement 1, Zoological fournal of the Linnean Society 50, 117-130.

Clemens, W. A., Lillegraven, J. A., Lindsay, E. H. \& Simpson, G. G. 1979. Where, when and what-a survey of known Mesozoic mammal distribution. In Mesozoic mammals: the first two-thirds of mammalian history (eds Lillegraven, J. A., Kielan-Jaworowska, Z. \& Clemens, W. A.), pp. 7-58. (University of California Press, Berkeley).

Clemens, W. A. \& Mills, J.R.E. 1971. Review of Peramus tenuirostris Owen (Eupantotheria, Mammalia). Bulletin of the British Museum (Natural History) Geology 20, 89-113.

Crompton, A.W. \& Kielan-Jaworowska, Z. 1978. Molar structure and occlusion in Cretaceous therian mammals. In Studies in the development, function and evolution of the teeth (eds Butler, P.M. \& Joysey, K.A.), pp. 249-287 (Academic Press, London).

Crusafont, M. \& Adrover, R. 1966. El primer representante de la clase mamíferos hallado en el Mesozoico de España. Teruel 35, 139-143.

Crusafont, M. \& Gibert, J. 1976. Los primeros multituberculados de España. Nota preliminar. Acta Geológica Hispánica 11, 57-64.

Cuenca Bescós, G., Amo, O., Aurell, M., Buscalioni, A. D., Canudo, J. I., Laplana, C., Pérez-Oñate, J., Ruiz-Omeñaca, J. I., Sanz, J. L. \& Soria, A. R. 1994. Los vertebrados del 
tránsito Jurásico-Cretácico de Galve (Teruel). Comunicaciones de las X fornadas de Paleontología, Madrid, pp. 50-53 (Sociedad Española de Paleontología, Madrid).

Cuenca Bescós, G., Canudo, J. I., Diez-Ferrer, B., Ruiz-Omeñaca, J. I. \& Soria, A. R. 1995. Los mamíferos del Barremiense (Cretácico Inferior) de España. Comunicaciones de las XI fornadas de Paleontología, Tremp, pp. 78-82 (Sociedad Española de Paleontología, Madrid).

Dashzeveg, D. 1979. Arguimus khosbajari gen. n., sp. n., (Peramuridae, Eupantotheria) from the Lower Cretaceous of Mongolia. Acta Palaeontologica Polonica 24, 199-204.

Dashzeveg, D. 1994. Two previously unknown Eupantotheres (Mammalia, Eupantotheria). American Museum Novitates 3107, 1-11.

Díaz-Molina, M., Yébenes, A., Goy, A. \& Sanz, J. L. 1984. Landscapes inhabited by Upper Jurassic/Lower Cretaceous archosaurs (Galve, Teruel, Spain). Third Symposium on Mesozoic Terrestrial Ecosystems, Tübingen, pp. 67-72 (ATTEMPTO Verlag, Tübingen).

Freeman, E. F. 1979. A middle Jurassic mammal bed from Oxfordshire. Palaeontology 22, $135-166$.

Hahn, G. 1971. Contribuição para o conhecimento da Fauna do Kimeridgiano da Mina de Lignito Guimarota (Leiria, Portugal. II Parte. III. The dentition of the Paulchoffatiidae (Multituberculata, Upper Jurassic). Serviços Geológicos de Portugal, Memória (Nova Série) 17, 7-39.

Hahn, G. 1987. Neue Beobachtungen zum Schadel-und Gebiss-Bau der Paulchoffatiidae (Multituberculata, Ober - Jura). Palaeovertebrata 17, 155-196.

Hahn, G. 1993. The systematic arrangement of the Paulchoffatiidae (Multituberculata) revisited. Geologica et Palaeontologica 27, 201-214.

Hahn, G. \& Hahn, R. 1992. Neue Multituberculaten-Zähne aus der Unter-Kreide (Barremium) von Spanien (Galve und Uña). Geologica et Palaeontologica 26, 143-162.

Henkel, S. \& Krebs, B. 1969. Zwei Säugetier-Unterkiefer aus der Unteren Kreide von Uña (Prov. Cuenca, Spanien). Neues Fahrbuch für Geologie und Paläontologie, Monatshefte 8, 449-463.

Jacobs, L., Congleton, J., Brunet, M., Dejax, J., Flynn, L., Hell, J. V. \& Mouchelin, G. 1988. Mammal teeth from the Cretaceous of Africa. Nature 336, 158-160.

Kielan-Jaworowska, Z. \& Ensom, P. C. 1992. Multituberculate mammals from the Upper Jurassic Purbeck Limestone Formation of southern England. Palaeontology 35, 95-126.

Kielan-Jaworowska, Z. \& Ensom, P. C. 1994. Tiny plagiaulacoid multituberculate mammals from the Purbeck Limestone Formation of Dorset, England. Palaeontology 37, 17-31.

Kielan-Jaworowska, Z. 1992. Interrelationships of Mesozoic mammals. Historical Biology 6, 185-202.

Kielan-Jaworowska, Z., Dashzeveg, D. \& Trofimov, B. A. 1987. Early Cretaceous multituberculates from Mongolia and a comparison with Late Jurassic forms. Acta Palaeontologica Polonica 32, 3-47.

Kraus, M. J. 1979. Eupantotheria. In Mesozoic mammals: the first two-thirds of mammalian history (eds Lillegraven, J. A., Kielan-Jaworowska, Z. \& Clemens, W. A.), pp. 162-171. (University of California Press, Berkeley).

Krebs, B. 1980. The search for Mesozoic mammals in Spain and Portugal. Mesozoic Vertebrate Life 1, 23-25.

Krebs, B. 1985. Theria (Mammalia) aus der unterkreide von Galve (Provinz Teruel, Spanien). Berliner Geowissenschaftliche Abhandlungen A 60, 29-48.

Krebs, B. 1993. Das Gebiß von Crusafontia (Eupantotheria, Mammalia)-Funde aus der UnterKreide von Galve und Uña (Spanien). Berliner Geowissenschaftliche Abhandlungen E 9, 233-252.

Kühne, W. \& Crusafont, M. 1968. Mamíferos del Wealdiense de Uña, cerca de Cuenca. Acta Geológica Hispánica 3, 133-134.

Kühne, W. 1966. Découverte de dents de mammiféres dans le Wealden de Galve. Teruel 35, $159-161$.

Lillegraven, J. A., Kielan-Jaworowska, Z. \& Clemens, W. A. (eds) 1979. Mesozoic mammals: the first two-thirds of mammalian history, $311 \mathrm{pp}$. (University of California Press, Berkeley).

Martín-Closas, C. 1989. Els caròfits del Cretaci inferior de les conques perifériques del Bloc de l'Ebre. $\mathrm{PhD}$ Thesis, Universidad de Barcelona, $581 \mathrm{pp}$.

McKenna, M. 1975. Toward a phylogenetic classification of the Mammalia. In Phylogeny of the primates (eds Luckett and Szalay, F. S.), pp. 21-46 (Cambridge University Press, Cambridge).

Mohr, B. A. R. 1987. Mikrofloren aus Vertebraten-führenden Unterkreide-Schichten bei Galve und Uña (Ostspanien). Berliner Geowissenschaftliche Abhandlungen A 86, 69-85.

Prothero, D. R. 1981. New Jurassic mammals from Como Bluff, Wyoming, and the interrelationships of non-tribosphenic Theria. Bulletin of the American Museum of Natural History 167, 277-326.

Richter, A. 1994. Lacertilia aus der Unteren Kreide von Uña und Galve (Spanien) und Anoual (Marokko). Berliner Geowissenschaftliche Abhandlungen E 14, 147 pp.

Sanz, J. L. (ed.) 1987. Geología y Paleontología (Arcosaurios) de los yacimientos cretácicos de Galve (Teruel) y Tremp (Lérida). Estudios Geológicos, Volumen extraordinario Galve-Tremp, $110 \mathrm{pp}$.

Schudack, M. 1989. Charophytenfloren aus den unterkretazischen Vertebraten-Fundschichten bei Galve und Uña (Ostspanien). Berliner Geowissenschaftliche Abhandlungen A 106, 409-443.

Sigogneau-Russell, D. 1988. Découverte de mammiféres dans le Mésozoique moyen d'Afrique. Comptes Rendus de l'Académie des Sciences, Paris, II 307, 1045-1050. 
Sigogneau-Russell, D. 1991. Découverte du premier mammifére tribosphénique du Mésozoique africain. Comptes Rendus de l'Académie des Sciences, Paris, II 313, 1635-1640.

Sigogneau-Russell, D. 1992. Hypomylos phelizoni nov. gen. nov. sp., une étape précoce de l'évolution de la molaire tribosphénique (Crétacé basal du Maroc). Geobios 25, 389-393.

Sigogneau-Russell, D. \& Ensom, P. 1994. Découverte, dans le Groupe de Purbeck (Berriasien, Angleterre), du plus ancien témoignage de l'existence de mammiféres tribosphéniques. Comptes Rendus de l'Académie des Sciences, Paris, II 319, 833-838.

Simpson, G.G. 1928. A catalogue of the Mesozoic Mammalia in the geological department of the British Museum, 215 pp. (British Museum, Natural History, London).

Soria, A. R., Meléndez, A., Cuenca-Bescós, G., Canudo, J. I. \& Liesa, C. L. 1995. Los sistemas lacustres del Cretácico inferior de la Cordillera Ibérica Central: La Cubeta de Aliaga. In Guia de Excursiones XIII Congreso Español de Sedimentología, Teruel, (eds Meléndez, A. \& Aurell, M.) pp. 91-141 (Universidad de Zaragoza, Zaragoza). 